\title{
NOTE
}

\section{New records and distribution extension of Pimelodus absconditus Azpelicueta, 1995 (Siluriformes: Pimelodidae) and Triportheus nematurus (Kner, 1858) (Characiformes: Triportheidae), in Uruguay.}

\author{
Wilson S. Serra ${ }^{1,2 *}$, Franco Teixeira-de-Mello ${ }^{3}$, Alejandro D’Anatro², Nicolás Vidal2,3, Iván González- \\ Bergonzoni ${ }^{2,4}$, Daniel García², Malvina Masdeu ${ }^{3}$, Javier Lenzi` ${ }^{5}$ Jukka Tana ${ }^{6}$. \\ 1 Museo Nacional de Historia Natural, Departamento de Zoología, Sección Ictiología. CC. 399, CP. 11000. \\ Montevideo, Uruguay. \\ 2 Facultad de Ciencias, Dpto. de Ecología y Evolución. Iguá 4225, CP 11400. Montevideo, Uruguay. \\ 3 Ecología y Rehabilitación de Sistemas Acuáticos, Centro Universitario Regional del Este, Universidad de la \\ República. Tacuarembó entre Saravia y Bvar. Artigas. CP 2000. Maldonado, Uruguay. \\ 4 Laboratorio de Etología, Ecología y Evolución, Instituto de Investigaciones Biológicas Clemente Estable, \\ Montevideo Uruguay. \\ 5 Centro de Investigación y Conservación Marina - CICMAR, Av. Gianatasio Km.30.5, El Pinar, Canelones, \\ Uruguay. \\ 6 ÅF-Consult Ltd, Bertel Jungin aukio 9, FI-02600 Espoo, Finland \\ * e-mail: serraelbicho@gmail.com
}

\begin{abstract}
Pimelodus absconditus and Triportheus nematurus are two poorly known species poorly represented in Uruguay. We report new records of both species, with implications on their geographical distribution.
\end{abstract}

Key words: Pimelodus absconditus, Triportheus nematurus, Uruguay River, Uruguay.

\section{RESUMEN}

Nuevos registros y ampliación de la distribución de Pimelodus absconditus Azpelicueta, 1995 (Siluriformes: Pimelodidae) y Triportheus nematurus (Kner, 1858) (Characiformes: Triportheidae), en Uruguay. Pimelodus absconditus y Triportheus nematurus son dos especies poco conocidas en Uruguay. Reportamos nuevos registros de las mismas para el país, con comentarios acerca de su distribución geográfica.

Palabras clave: Pimelodus absconditus, Triportheus nematurus, Río Uruguay, Uruguay.

The Neotropical freshwater ichthyofauna is highly diverse, with approximately 4,035 fish species belonging to 705 genera (Levêque et al., 2008). However, the expected number of fish species for this region is even higher, ranging from 5,000 to 8,000 (Lundberg et al., 2000). The Uruguayan freshwater ichthyofauna diversity, as occurs in the Neotropical region, is underestimated. The lists of fish species presence, or potentially present in
Uruguayan freshwaters systems have been published in the last seventy years (Carrera, 1976; Nión et al., 2002; Litz \& Koerber, 2014). These lists were elaborated considering species formerly cited for Uruguay in national or international publications, species cited for bordering countries, voucher specimens in collections, and photographs. However, most of these works do not provide distributional data, and many of the species mentioned are not registered in scientific collections records. In recent years, the presence of some of these unregistered species have been confirmed, and the presence of species not previously registered for Uruguay has been reported (Zarucki et al., 2010; Serra et al., 2011; Duarte et al., 2013; Serra et al., 2012; 2013; Loureiro et al., 2013; Serra et al., 2014).

The aim of this work is to confirm the presence in Uruguay of Triportheus nematurus (Kner, 1858) and Pimelodus absconditus Azpelicueta, 1995, two rare species for the lower Uruguay river.

Specimens recorded were deposited in the collections of Centro Universitario Regional Este de Maldonado (CURE-ICT), Museo Nacional de Historia Natural de Montevideo (MHNM), and Facultad de Ciencias, UdelaR (ZVC-P), Uruguay. The taxonomic identification of $P$. absconditus specimens was made using the original description of the species (Azpelicueta, 1995). In the case of Triportheus the identification was based on the revision of the genus made by Malabarba (2004). Measurements (nearest $0.1 \mathrm{~mm}$ ) were taken with a digital caliper. Standard length (SL) was measured from tip of snout to hypural joint. 


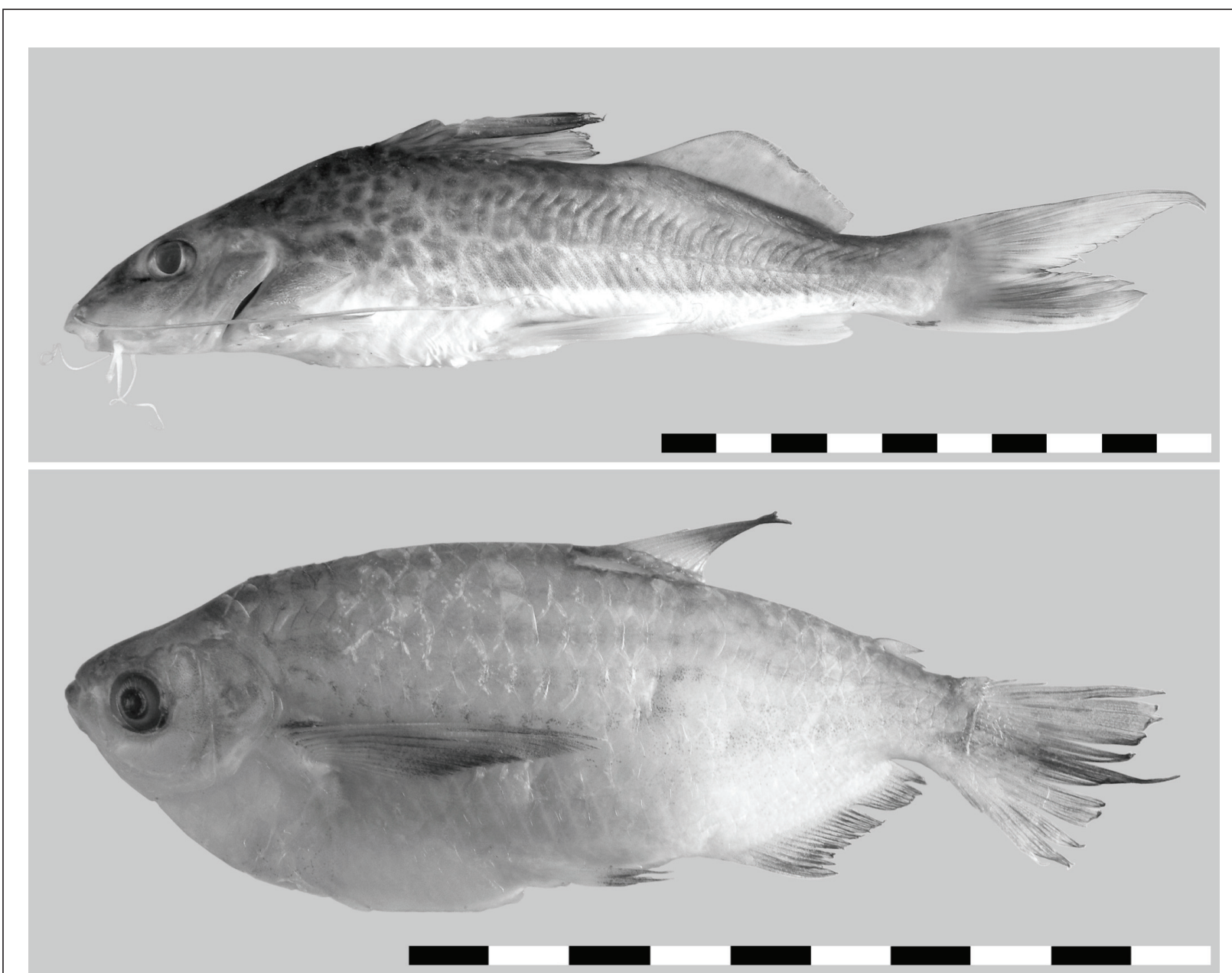

Fig. 1. Preserved specimens of Pimelodus absconditus (MHNM 3502, above) and Triportheus nematurus (CURE-ICT 014 , below). Scalebar total length represent $10 \mathrm{~cm}$.

\section{Pimelodus absconditus (Figure 1)}

P. absconditus is easily distinguished from other species of the genus present in Río de la Plata basin by the following combination of characters: presence of irregular dots of different sizes, more conspicuous in the anterior region of the body, and subterminal mouth with thick lips. The known distribution extends across the middle Paraná River basin and middle Río Uruguay Basin in Argentina (Azpelicueta, 1995; Liotta, 2005). During recent field works in lower Río Uruguay, we have collected specimens of $P$. absconditus, confirming its presence in the national territory. The present records belong to Nuevo Berlín (320 59'17"S,

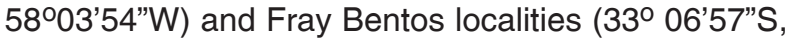
$58^{\circ} 16^{\prime 22}$ 'W) in (Río Negro Department, Uruguay). Additional specimens were found in the ichthyological collection of Facultad de Ciencias, from lower Cuareim River and Río Uruguay, (Artigas Department, Uruguay) (Appendix 1 and Figure 2).
The report of $P$. absconditus in the work of Nión et al. (2002) probably responds to the presence of this species in Argentina, because no previous studies or identified specimens in collections were found (historical specimens of $P$. absconditus were classified as Pimelodus maculatus in following ZVC-P records). Subsequent studies (e.g. Lundberg \& Littmann, 2003; Litz \& Koerber, 2014) did not offer information about their sources for these records.

\section{Triportheus nematurus (Figure 1)}

Triportheus nematurus is distinguished from $T$. pantanensis Malabarba, 2004 (the other species of the genus known to Río de la Plata basin) by the following combination of characters: scales in lateral line 33 to 37 , and gill rakers on the lower limb of the first gill arch ranging to 38 from 48, versus 28 to 33 lateral line scales and 26 to 33 gill rakers in $T$. 


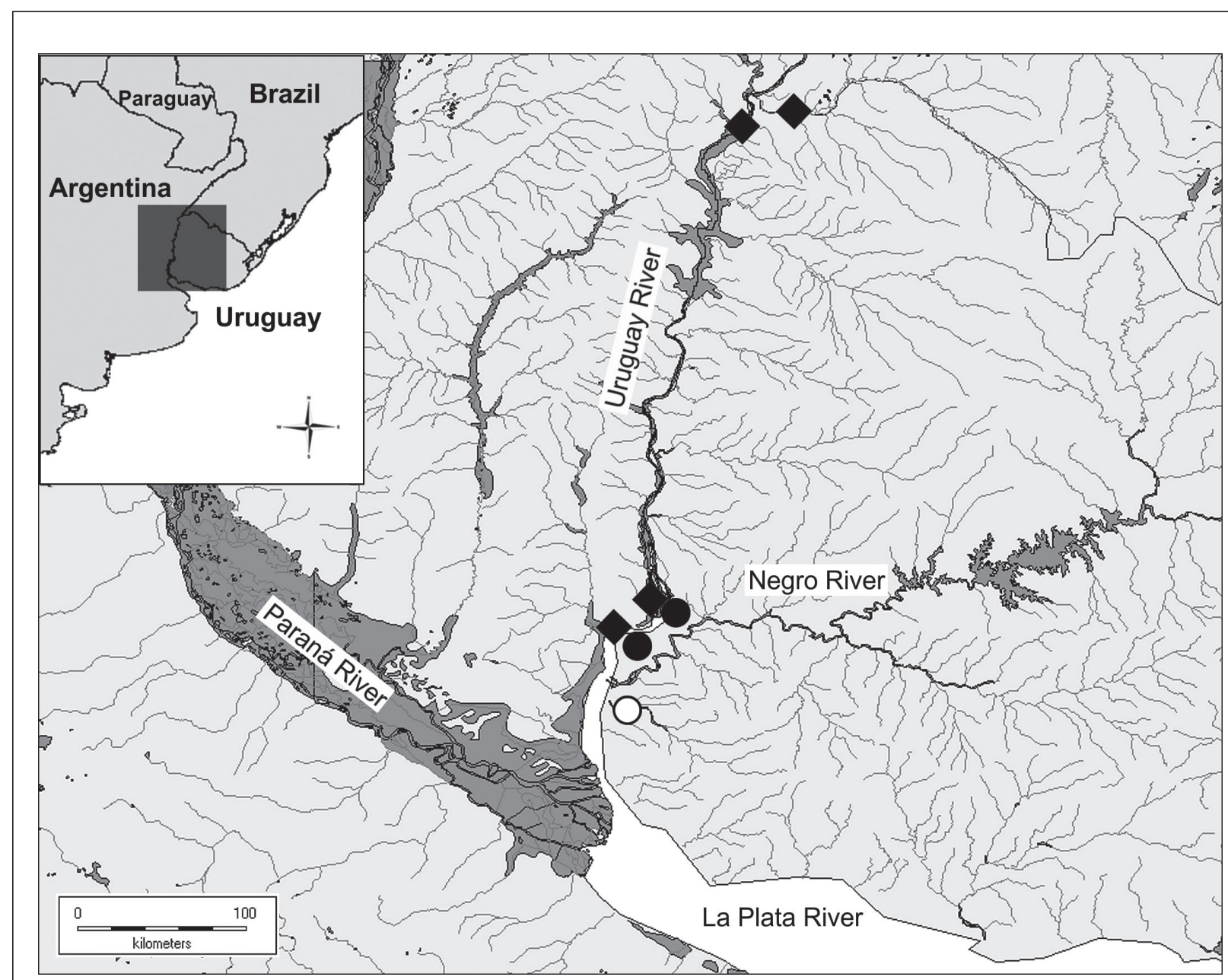

Fig. 2. Geographic distribution of Pimelodus absconditus (diamonds) and Triportheus nematurus (black dots) in Uruguay. Empty dot corresponds to the specimen cited in Vaz-Ferreira et al. (1983).

pantanensis (Malabarba, 2004). The known distribution of $T$. nematurus extends across the Paraguay and Paraná rivers basins (Malabarba, 2004). Based on the examination of the specimen deposited in the ichthyological collection of Facultad de Ciencias, previously cited originally as T. paranensis (Vaz-Ferreira et al., 1983; Nión et al., 2002; Loureiro et al., 2013), we confirmed that it was indeed $T$. nematurus, as suggested by Litz and Koerber (2014). The new records belong to the lower section of Río Uruguay (Espinillo Stream, Soriano Department, and Nuevo Berlín and Fray Bentos, Río Negro Department) (Appendix 1 and Figure 2).

These records set a new distribution range for these species in the Río de la Plata basin. Our observations extend the distribution of $P$. absconditus ca. $90 \mathrm{~km}$ southwards in Río Uruguay basin. Finally, the recent records of $T$. nematurus support the presence of this species in Río Uruguay, considering that this species was reported for the region based on the record of a single individual in the 1960'.

We dedicate this manuscript to the memory of Diego Larrea, a great and beloved colleague who was and is still present in the sampling campaigns of the Río Uruguay. Samplings were conducted on the context of UPM Fray Bentos pulp mill impact assessment. We greatly thank to Gervasio González for providing logistical support during the development of this study. We thank Mercedes Azpelicueta (Museo de La Plata) for the copy of the description of $P$. absconditus.

\section{BIBLIOGRAPHY}

Azpelicueta M.M. 1995. Pimelodus absconditus, a new species of pimelodid catfish from the La PlataBasin (Siluriformes: Pimelodidae). 
Ichthyological Exploration of Freshwaters, 6(1): 71-76.

Carrera R. 1976. Peces. En A. Langguth (Ed.) Lista de Vertebrados del Uruguay, pp. 33-53. Museo Nacional de Historia Natural, Facultad de Humanidades y Ciencias, Departamento de Zoología de Vertebrados, Montevideo, Uruguay..De Buen F. 1950. El mar de Solís y su fauna de peces. II Parte. Publicaciones Científicas, Servicio Oceanográfico y de Pesca, Ministerio de Industrias y Trabajo, Montevideo, 2: 45-144.

Duarte A., Serra W.S., Zarucki M. \& Loureiro M. 2013. First records of Dormitator maculatus (Eleotridae) and Ctenogobius shufeldti (Gobiidae) in Uruguay (Actinopterygii: Gobiiformes). Boletín de la Sociedad Zoológica del Uruguay, 22 (2): 99-103.

Levêque C., Oberdorff T., Paugy D., Stiassny M.L.J. \& Tedesco P.A. 2008. Global diversity of fish (Pisces) in freshwater. Hydrobiologia, 595(1): 545-567.

Liotta J. 2005. Distribución geográfica de los peces de aguas continentales de la República Argentina. Serie Documentos $\mathrm{N} \square$ 3. ProBiota FCNyM, UNLP. Buenos Aires, Argentina. 653 pp.

Litz T.O. \& Koerber S. 2014. Check List of the Freshwater Fishes of Uruguay (CLOFF-UY). Ichthyological Contributions of Peces Criollos, 28: 1-40.

Loureiro M., Zarucki M., González I., Vidal N. \& Fabiano G. 2013. Peces continentales. En A. Soutullo, C. Clavijo \& J.A. Martínez-Lanfranco (Eds.). Especies prioritarias para la conservación en Uruguay - Vertebrados, moluscos continentales y plantas vasculares, pp. 91-112. SNAP/ DINAMA/MVOTMA y DiCyT/MEC, Montevideo, Uruguay.

Lundberg J.G. \& Littmann M.W. 2003. Family Pimelodidae (Long-whiskered catfishes). En R.E. Reis, S.O. Kullander \& C.J. Ferraris, Jr. (Eds.). Check List of the Freshwater Fishes of South and Central America, pp. 432-446. EDIPUCRS, Porto Alegre, Rio Grande do Sul, Brazil.

Lundberg J.G., Kottelat M., Smith G.R., Stiassny M. \& Gill A.C. 2000. So many fishes, so little time: An overview of recent ichthyological discovery in continental waters. Annals Missouri Botanical Garden, 87: 26-62.Malabarba M.C.S.L. 2004. Revision of the Neotropical genus Triportheus Cope, 1872 (Characiformes, Characidae). Neotropical Ichthyology, 2(4): 167-204.

Nión H., Ríos C. \& Menezes P. 2002. Peces del Uruguay. Lista Sistemática y Nombres Comunes. DINARA, Infopesca. Montevideo, Uruguay. $115 \mathrm{pp}$

Serra W.S., Duarte A., Burress E.D. \& Loureiro M.
2011. Perciformes, Cichlidae, Crenicichla tendybaguassu Lucena and Kullander, 1992: First record for Uruguay. Check List, 7(3): 357359.

Serra W.S., Duarte A., Zarucki M., Fabiano G. \& Loureiro M. 2012. New records and distribution extension of Potamorhina squamoralevis (Braga \& Azpelicueta, 1983) (Characiformes) and Plagioscion ternetzi Boulenger, 1895 (Perciformes) in Uruguay. Boletín de la Sociedad Zoológica del Uruguay ( $2^{\underline{a}}$ época), 21(1-2): 65-69.

Serra S., Bessonart J., Teixeira de Mello F., Duarte A., Malabarba L. \& Loureiro M. 2014. Peces del Río Negro. MGAP-DINARA, Montevideo, Uruguay. $208 \mathrm{pp}$.

Serra W.S., Zarucki M., Duarte A., Burress E.D., Teixeira de Mello F., González-Bergonzoni I. \& Loureiro. M. 2013. First report of four characiform fishes (Ostariophysi: Characiformes) for Uruguay. Check List, 9(6): 1576-1579.

Vaz-Ferreira R., Nion H., Ríos C. \& Pérez-Castellanos M.E. 1983. Notas sobre peces de agua dulce del Uruguay. Resúmenes y Comunicaciones de las III Jornadas de Ciencias Naturales, Montevideo, pp. 63-65.

Zarucki M., Gonzalez-Bergonzoni I., Teixeira-de Mello F., Duarte A., Serra S., Quintans F. \& Loureiro M. 2010. New records of freshwater fish for Uruguay. Check List, 6(2): 191-194.

\section{APPENDIX 1. MUSEUM RECORDS OF SPECIMEN ANALYZED.}

P. absconditus: MHNM 3502, 2 ex. (114,2-162,0 mm SL.), Nuevo Berlín, Uruguay River, (32058'52"S, 58¹6'39”W), Río Negro Department, Uruguay, Col.: W.S. Serra, F. Teixeira de Mello, M. Masdeu, A. D’Anatro, D. García, J. Lenzi \& J. Tana, 26/IV/2014; MHNM 3503, 1 ex. (75,6 mm SL.), Yaguareté bay, Fray Bentos, Uruguay River, (3306'35'S, 58¹6'39”W), Río Negro Department, Uruguay, Col.: W.S. Serra, F. Teixeira de Mello, M. Masdeu, A. D’Anatro, D. García, J. Lenzi \& J. Tana, 27/IV/2014; CURE-ICT 016, 1 ex. (153,1 mm SL.), Nuevo Berlín, Uruguay River, (32058'52» S, 58¹6'39” W), Río Negro Department, Uruguay, Col.: W.S. Serra, F. Teixeira de Mello, M. Masdeu, A. D'Anatro, D. García, J. Lenzi \& J. Tana, 26/IV/2014; ZVC-P 8311, 1 ex. (50,7 mm SL), "El Ombú”, mouth of Yucutujá Stream, Cuareim River (30018'10»S, 57023'17”W), Artigas Department, Uruguay, Col.: “Lab. Zoología”, II/1952; ZVC-P 13197, 1 ex. (86,1 mm SL), "Arrocera Conti”, in front of Isla del Zapallo, Uruguay River (3031'45”S, 57052'43”W), Artigas Department, Uruguay, Col.: A. Langguth \& $\mathrm{E}$ Maciel, 29/IX/1976.

T. nematurus: ZVC-P 486, 1 ex. (103,2 mm SL.), 
Espinillo Stream, Soriano Department, Uruguay, Col.: Carbonell, Moné \& Morey, 14///1962; CURE-ICT 014, 1 ex. (114,9 mm SL.), Nuevo Berlín, Uruguay River, (32058'52”S, 58¹6'39”W), Río Negro Department, Uruguay, Col.: F.Teixeira de Mello, I. GonzálezBergonzoni, N. Vidal, M. Masdeu, A. D'Anatro, D. Larrea \& J. Tana, 17/IV/2010; CURE-ICT 015, 1 ex. (122,6mm. SL.), Yaguareté bay, Fray Bentos, Uruguay River, (3306'35"S, 58¹6'39”W), Río Negro
Department, Uruguay, Col.: F.Teixeira de Mello, I. González-Bergonzoni, N. Vidal, M. Masdeu, A. D’Anatro, D. Larrea \& J. Tana, 18/IV/2010.

Fecha de Recepción: 7 de julio de 2015 Fecha de Aceptación: 25 de noviembre de 2016 